Diabetologia 9, 6-12(1973)

(C) by Springer-Verlag 1973

\title{
Inhibition of Intestinal Amino Acid Transport by Blood Sugar Lowering Biguanides*
}

\author{
W.F. Caspary and W. Creutzfeldt \\ Division of Gastroenterology and Metabolism, Department of Medicine, University of Goettingen, Germany (F.R.G.)
}

Received: August 23, 1972, accepted: October 26, 1972

Summary. The effect of blood-glucose lowering bigusnides (phenethyl- and butylbiguanide) on active intestinal transport of different amino acids has been tested in hamster small intestine in vitro. - . Biguanides inhibited active transport of all amino acids tested. The inhibitory effect of biguanides increased with incubation time, was more pronounced after preincubation of intestinal tissue and was found to be non-competitive. The minimal inhibitory concentration of phenethylbiguanide on amino acid transport was $5 \times 10^{-1} \mathrm{M}$. - ${ }^{14} \mathrm{C}$-butylbiguanide was found to be transported into hamster small intestine by a concentration-independent, energy-independent uptake mechanism and was accumulated in intestinal tissue against a concentration gradient. - In accord with ear- lier results on the inhibitory effect of biguanides on active intestinal hexose transport it is concluded that biguanides do not act as specific inhibitors for glucose transport, but rather affect active, energy-requiring intestinal transport mechanisms in general (hexose-, amino acid-, calcium- and myo-inositol transport), most likely due to their known inhibitory effect on mitochondrial respiration, thus depriving mucosal cells of ATP required to translocate substrates against a concentration gradient.

Key words : Biguanides, intestinal amino acid transport, phenethylbiguanide, butylbiguanide, biguanide transport.

\section{Introduction}

Evidence that biguanides are inhibiting or delaying glucose absorption from the intestine has been reported by several investigators $[3,4,7,8,14,20,21$, $23,24]$. The in vitro effect of blood sugar lowering biguanides on active transport of several substrates for the common $\mathrm{Na}^{+}$-dependent active sugar transport system can be explained by inhibition of active trans. port of hexoses [7]. Transport of substrates having a high affinity for the transport system (D-glucose, D-galactose) was more strongly inhibited by biguanides than transport of low affinity substrates [7], whereas uptake of $\mathrm{D}$-fructose which is not a substrate for the common $\mathrm{Na}^{+}$-dependent sugar pathway was not affected [7].

Transport of amino acids in hamster small intestine exhibits similar features to sugar transport, namely: energy-dependence, saturation transport kinetics, accumulation against a concentration gradient, $\mathrm{Na}^{+}$. dependency $[13,25]$. The purpose of our present study was to find out whether biguanides inhibit transport of actively transported sugars only, thus having a specific effect on sugar absorption, or inhibit, also, active intestinal transport of amino acids using the different amino acid transport pathways [25]. If the latter were true one could assume that biguanides affect active transport processes per se, possibly by depriving the mucosal epithelial cell of energy required to translocate substrates against a concentration

* Part of this work has been presented at the International Diabetes Congress, Buenos Aires, Argentina, August 1970 and at the Meeting of German and Italian Pharmacology Society, Heidelberg, September 1970. gradient. This would be a very likely possibility since biguanides are known to be strong inhibitors of mitochondrial respiration [16]. Since myo-inositol, structurally very similar to D-glucose, is actively transported in the intestine by an entry mechanism different from the common hexose pathway [6], the effect of biguanides on transport of myo-inositol was also tested.

\section{Methods}

The present experiments were performed by the in vitro method of Crane and Mandelstam [10] as modified in a more recent publication [5]. Hamsters, of $80 \pm 15 \mathrm{~g}$ weight were fasted overnight. Approximately $200-300 \mathrm{~g}$, wet weight, of everted segments of small intestine were placed in $25 \mathrm{ml}$ Erlenmeyer flask8, containing 5 or $10 \mathrm{ml}$ of Krebs-Henseleit phosphate buffer with the appropriate substrates added. The buffer was gassed with pure oxygen and incubations carried out in a Dubnoff shaking water bath $\left(37^{\circ} \mathrm{C}\right)$ for the time indicated in the graphs. D-mannitol was used as a marker of extracellular space $[5,9]$. In preincubation experiments intestinal tissue was incubated either in buffer alone or in buffer with different concentrations of biguanides for the time indicated in the graphs, removed from the flasks, rinsed for 15 sec with buffer and transferred to a new medium containing substrates without biguanides.

\section{Compounds}

Amino acids and myo-inositol were obtained from Sigma (St. Louis, Miss., USA) and were of analytical grade, which was confirmed by chromatography with different solvent systems. Phenethylbiguanide-hydrochloride was obtained from USV Pharmaceutical Corporation (New York), butylbiguanide-hydrochloride from Chemie Grünenthal (Stolberg/Rheinland, Germany), methylbiguanide from Dr. Heinz Haury (München). ${ }^{14}$-C- 
butyl-biguanide (spec. activity $11.4 \mu \mathrm{Ci} / \mathrm{mg}$ ) was a gift from Dr. R. Beckmann (Chemie Grünenthal, Stolberg/ Rheinland, Germany). Labelled compounds ((U) $-{ }^{14} \mathrm{C}-\mathrm{L}$ leucine, ${ }^{14} \mathrm{C}$-L-methionine, ${ }^{14} \mathrm{C}$-L-lysine, ${ }^{14} \mathrm{C}-\mathrm{L}$-glycine, ${ }^{14} \mathrm{C}$-L-proline, ${ }^{14} \mathrm{C}$ - $x$-aminoisobutric acid , ${ }^{3} \mathrm{H}$-myo-inositol, ${ }^{3} \mathrm{H}$ and ${ }^{14} \mathrm{C}$-D.mannitol) were obtained from New England Nuclear or Amersham.

\section{Analytical method}

Incubations were terminated by removal of the tissue which then was processed as described by Crane and Mandelstam [10]. Radioactivity of the medium and tissue water extracts was assayed with a Packard Liquid Scintillation System using the channel ratio method for quench-correction.

\section{Calculation of data}

Results are expressed in:

per cent filling $=100 \times \frac{\mu \mathrm{moles} / \mathrm{ml} \text { tissue water }}{\mu \mathrm{moles} / \mathrm{ml} \text { initial medium }}$

or in $\mu \mathrm{moles} / \mathrm{ml}$ tissue water per unit time in kinetic experiments to express velocity of substrate uptake [5]. A figure $>100$ moans accumulation of the substrate in the tissue water space compared to the medium substrate concentration.

The data aro corrected for extracellular space [9]. Results are given as means + S.E.M.

After incubation with the various labelled compounds tissue water extracts and incubation medium were subjected to paper chromatography using different solvent systems. More than $94 \%$ of the radioactivity of tissue water extracts was found in one peak, corresponding to the reference substrate (before incubation) when subjected to a Packard autoscanner and subsequent counting of the peak with a Liquid Scintillation System. This indicated that there were no appreciable amounts of metabolic products of the substrates used to measure transport into intestinal tissue.

\section{Results}

Since the inhibitory effect of biguanides on active sugar transport could be observed only after a minimum exposure of $5 \mathrm{~min}$ to biguanides [7] we studied the time-dependence of the inbibitory effect of biguanides on active in vitro transport of L-methionine, which is translocated in the intestine across the brush border membrane by the $\mathrm{Na}^{+}$-dependent active neutral amino acid transport system [25]. A significant inhibitory effect of phenethylbiguanide on uptake of L-methionine could be observed already after 5 min of incubation, when substrate and inhibitor were present simultaneously in the incubation medium. This effect was even more pronounced after 10 and $30 \mathrm{~min}$ of incubation (Fig. 1). Chromatographic examination of the tissue water extracts revealed that $95 \%$ of the radioactivity was unmetabolized L-methionine.

In order to find out whether biguanides might exert their inhibitory action from the mucosal side of the membrane only, possibly by competing with amino acids for a common carrier binding site, we preincubat. ed intestinal tissue with phenethylbiguanide for $15 \mathrm{~min}$, rinsed the tissue thoroughly for 30 sec with buffer and transferred the tissue to a new incubation medium containing the substrate (L-methionine) without phenethylbiguanide. Under these conditions inhibition of L-methionine uptake could be observed earlier (Fig. 2) and was more pronounced at 10 min of incubation compared to the first experiment (Fig. 1) where substrate and inhibitor were added simultane-

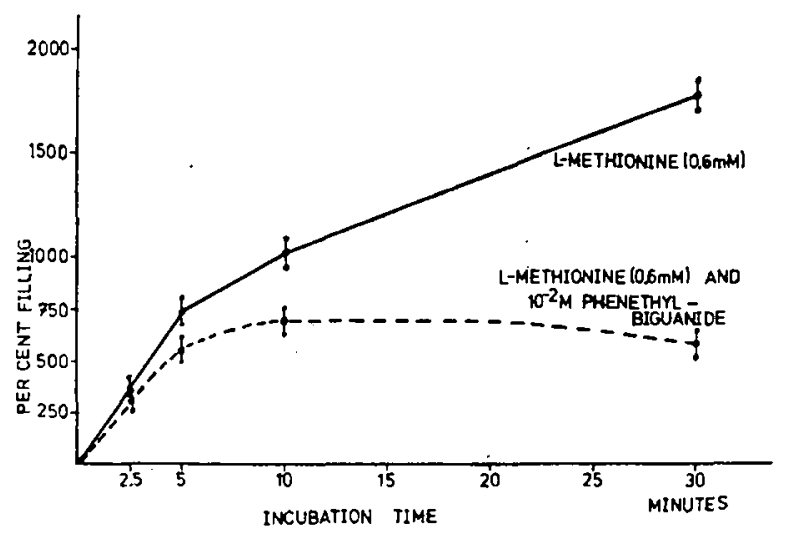

Fig. 1. Effect of phenethylbiguanide on time-dependent tissue accumulation of L-methionine. Substrate and inhibitor were added simultaneously. Rings of everted hamster small intestine were incubated for the time indicated in Krebs-Henseleit phosphate buffer under pure oxygen. Results are means of 5 experiments and are expressed as means $\pm \mathrm{SEM}$

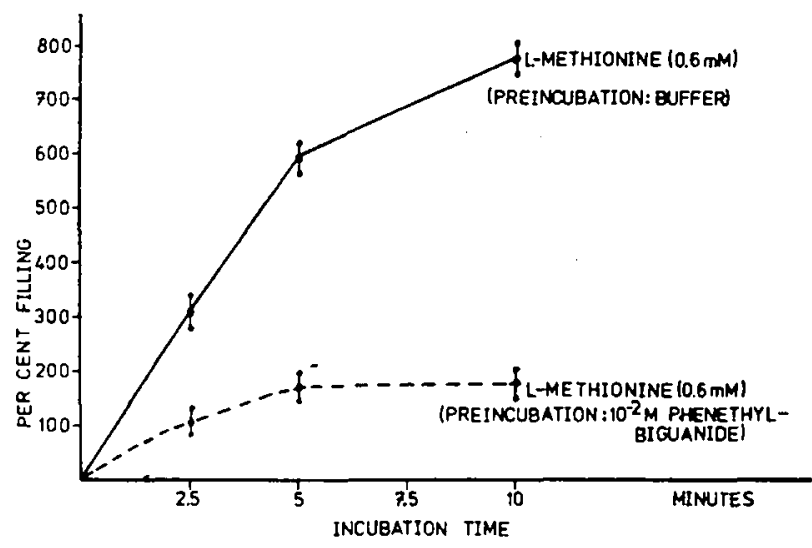

Fig. 2. Effect of intestinal tissue preincubation with phenethylbiguanide on subsequent uptake of L-methionine. Segments of everted hamster small intestine were preincubated either in Krebs-Henseleit phosphate buffer or buffer with addition of phenethylbiguanide $\left(10^{-2} \mathrm{M}\right)$ for $15 \mathrm{~min}$. Thereafter tissue was removed, rinsed for 30 sec with buffer and transferred to a new medium containing $\mathrm{L}$-methionine $(0.6 \mathrm{mM})$ and reincubated for the time indicated. The new medium did not contain phenethylbiguanide. Results are given as means \pm SEM $(n=6)$

ously. Preincubation with phenethylbiguanide and subsequent incubation with the substrate resulted in $76 \%$ inhibition of uptake after $10 \mathrm{~min}$ of incubation compared to $33 \%$ under conditions of simultaneous addition of substrate and inhibitor.

Measuring initial uptake rates of L-methionine in presence of different concentrations of phenethylbi- 
guanide, a non-competitive type of inhibition was obtained when the results were plotted according to the method of Dixon [17] (Fig. 3), indicating that biguanides do not compete with amino acids for a common receptor binding site but do affect maximal transport capacity of the amino acid transport system. Under the

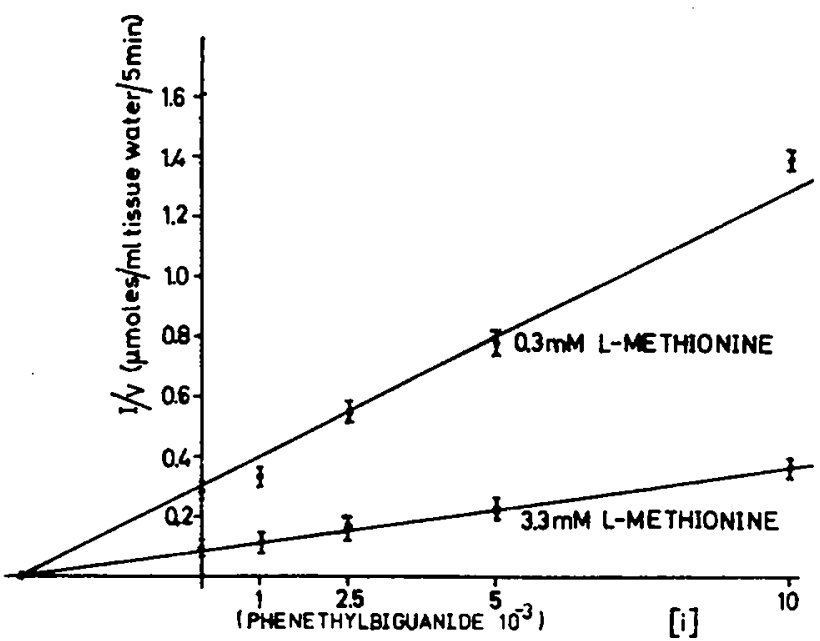

Fig. 3. Effect of different concentrations of phenethylbiguanide on concentration-dependent initial uptake-rates of L-methionine. Rings of everted hamster small intestine were incubated for $10 \mathrm{~min}$ with two concentrations of L-methionine at different concentrations of phenethylbiguanido (i). Results are expressed in umoles of Lmethionine uptake / $\mathrm{ml}$ of tissue water / unit time. The results [(1/V (velocity) versus i (inhibitor concentrations)] are plotted according to the method of Dixon [17].

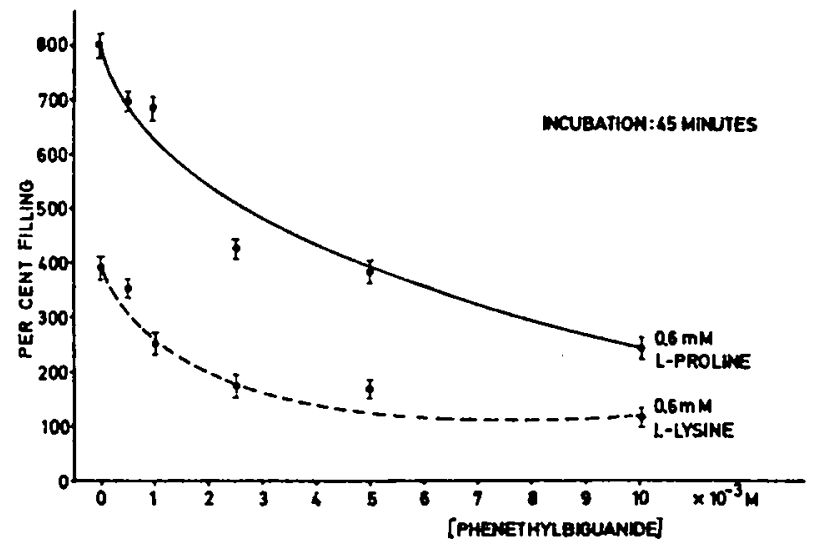

Fig. 4. Inhibitory effect of phenethylbiguanide on intestinal accumulation of L-lysine and L-proline. Segments of everted hamster small intestine were incubated for $45 \mathrm{~min}$ in Krebs-Henseleit phosphate buffer. Substrate and inhibitor were added simultaneously. Results are means of 4 experiments and are given as means $\pm S E M$

conditions employed the $\mathbf{K i}$ of phenethylbiguanide was $3 \times 10^{-3} \mathrm{M}$. As inhibition of amino acid uptake by biguanides increased with incubation time (Fig. 1 and 2) longer incubations would have revealed a lower half-maximal inhibitor concentration (Ki).

The minimal concentrations of phenethylbiguanide required to exert a significant inhibitory effect on accumulation of amino acids were $5 \times 10^{-4} \mathrm{M}$ (Table 1 ). In these experiments intestinal tissue was preincubated with different concentrations of phenethylbiguanide, but similar results were obtained when substrates ( $\mathrm{L}_{4}$ proline and L-lysine) and inhibitor were added simultaneously and the incubations carried out for $45 \mathrm{~min}$, thus allowing the biguanide to achieve an intracellular concentration high enough to exert its inhibitory effect (Fig. 4).

Butylbiguanide exhibited a similar inhibitory effect on uptake of amino acids (L-leucine, L-methionine, glycine and $\alpha$-aminoisobutyric acid) (Fig. 5) compared with phenethylbiguanide. The concentration of butylbiguanide required to achieve an equal inhibitory effect to $10^{-2} \mathrm{M}$ phenethylbiguanide was $2 \times 10^{-2} \mathrm{M}$. The time-dependent inhibitory effect of butylbiguanide on transport of L-leucine was equal to that of phenethylbiguanide. A significant inhibitory effect of both biguanides could be observed after 5 min of incubation (Fig. 6).

In order to demonstrate that phenethylbiguanide is also able to inhibit uptake of higher substrate concentrations, as was to be expected from a non-competitive type of inhibition, intestinal tissue was incubated with several amino acids at concentrations far below and far above their transport $\mathrm{Km}$-values (Table 2). Upake of L-proline, L-methionine, glycine, $\alpha$ aminoisobutyric acid, L-leucine, and L-lysine was inhibited by phenethylbiguanide if the substrates were present at concentrations of $30 \mathrm{mM}$ in the incubation medium. Active transport of myo-inositol is inhibited, too, by phenethylbiguanide.

In order to find out whether biguanides do exert their inhibitory effect by binding to the mucosal surface or after entry into the mucosal cells we measured tissue uptake of ${ }^{14} \mathrm{C}$-butylbiguanide. After $60 \mathrm{~min}$ of incubation butylbiguanide was accumulated against a concentration gradient (Fig. 7). Uptake was linear up to an incubation time of $20 \mathrm{~min}$. Accumulation of a substrate against a concentration gradient does, however, not necessarily mean that an active transport mechanism is involved. The uncoupling agent 2.4dinitrophenol, known to be a strong inhibitor of active transport processes, did not affect tissue uptake of butylbiguanide (Table 3). Addition of high concentrations of phenethylbiguanide and cold butylbiguanide to tracer concentrations of ${ }^{14} \mathrm{C}$-butylbiguanide did not affect uptake of ${ }^{14} \mathrm{C}$-butylbiguanide; these findings are consistent with a diffusional, energy-independent uptake mechanism for butylbiguanide in the intestine. An inhibitory effect on uptake of butylbiguanide was, however, observed in the presence of ouabain (Table 3). Rinsing of tissue incubated with ${ }^{14} \mathrm{C}$-butylbiguanide removed the amount of butylbiguanide located in the extracellular space, but did not affect intracellular concentrations of ${ }^{14} \mathrm{C}$-butylbiguanide. The fact that with increasing incubation time more butylbiguanide can be found in the tissue suggests entry of the substrate into the cells rather than surface binding. 


\section{Discussion}

Active transport of amino acids known to be transported across the intestinal brush border membrane by different transport systems was markedly inbibited in the presence of blood sugar lowering biguanides. This inhibitory effect was even more pronounced if intestinal tissue was preexposed to biguanides and subsequently incubated with the appropriate substrates. These findings might be explained by the rather slow rate of entry of biguanides (demonstrated active, energy-requiring transport systems in general. This is further confirmed by the observation that active transport of myo-inositol - a compound structurally very similar to. D-glucose, but having different carrier binding sites from D.glucose [6] - is also inhibited by phenethylbiguanide. Active intestinal transport of calcium is inhibited by higuanides, too [8].

Recent studies by Robinson [24] have shown that active transport of sugars and amino acids was inhibited by biguanides in dog small intestine and in dog kidney cortex slices. Robinson suggests that biguan-

Table 1. Effect of preincubation of intestinal tissue with phenethylbiguanide on subsequent tissue-uptake of $L$-leucine and $L$-methionine

\begin{tabular}{|c|c|c|c|c|}
\hline \multirow{2}{*}{ Preincubation medium } & \multicolumn{4}{|c|}{ Tissue-uptake (\%-filling) } \\
\hline & \multicolumn{2}{|c|}{ L-leucine-uptake } & \multicolumn{2}{|c|}{$\begin{array}{l}\text { I-methionine- } \\
\text { uptake }\end{array}$} \\
\hline $\begin{array}{l}\text { buffer } \\
\text { phenethylbiguanide }\left(5 \times 10^{-4} \mathrm{M}\right) \\
\text { phenethylbiguanide }\left(10^{-3} \mathrm{M}\right) \\
\text { phenethylbiguanide }\left(2.5 \times 10^{-3} \mathrm{M}\right) \\
\text { phenethylbiguanide }\left(5 \times 10^{-3} \mathrm{M}\right) \\
\text { phenethylbiguanide }\left(10^{-2} \mathrm{M}\right)\end{array}$ & $\begin{array}{l}718 \pm 34 \\
624 \pm 25 \\
587 \pm 28 \\
301 \pm 22 \\
243 \pm 15 \\
158 \pm 8\end{array}$ & $\begin{array}{l}(6) \\
(5) \\
(5) \\
(6) \\
(6) \\
(6)\end{array}$ & $\begin{array}{r}1044 \pm 20 \\
970 \pm 17 \\
977 \pm 15 \\
826 \pm 10 \\
511 \pm 15 \\
377 \pm 16\end{array}$ & $\begin{array}{l}(4) \\
(5) \\
(5) \\
(5) \\
(5) \\
(6)\end{array}$ \\
\hline
\end{tabular}

Segments of everted hamster small intestine wele preincubated for $15 \mathrm{~min}$ in Krebs-Henseleit phosphate buffer with addition of phenethylbiguanide at different concentrations. Tissue was then rinsed for 30 sec with buffer and transferred to a new medium containing either $0.6 \mathrm{mM}$ L-leucine or $0.6 \mathrm{mM} \mathrm{L}$-methionine without phenethylbiguanide and incibated under pure oxygen for further $30 \mathrm{~min}$. Results are means $\pm S E M$.

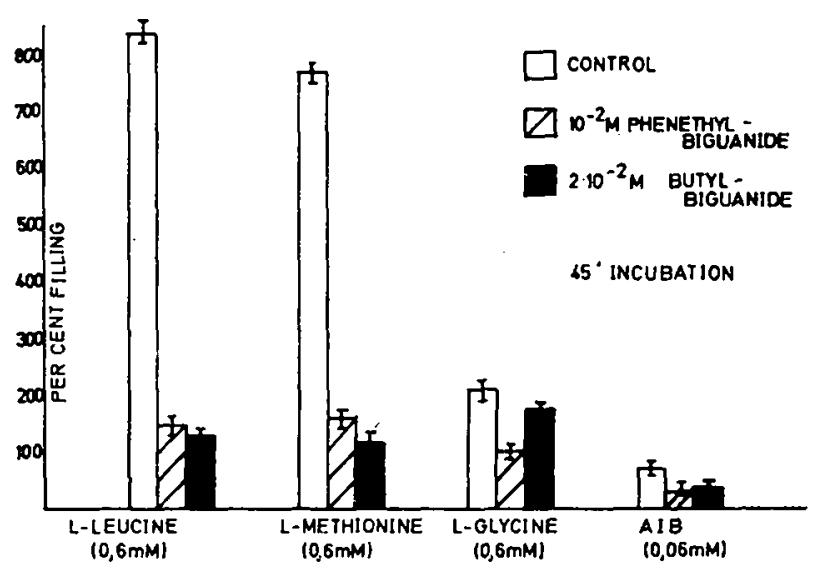

Fig. 5. Comparative inhibitory effoct of phenethyl. biguanide and butylbiguanide on intestinal tissue accumulation of differont amino acids. Substrates and inhibitor were added simultaneously. Incubation was for 45 min in Krebs-Henseleit phosphate buffer. Results are means of 5 experiments \pm SEM

for butylbiguanide) into the intestinal tissue (Fig. 7) and suggests that biguanides do exert their inhibitory effect from inside the tissue rather than at the mucosal surface. The inhibitory effect of biguanides on glucose absorption observed by many investigators $[3,4,7,8$, $14,20,23,24]$ seems, according to our results, not specific for the active sugar transport system. The results presented, in addition to earlier observations $[8,24]$, suggest that biguanides rather seem to affect

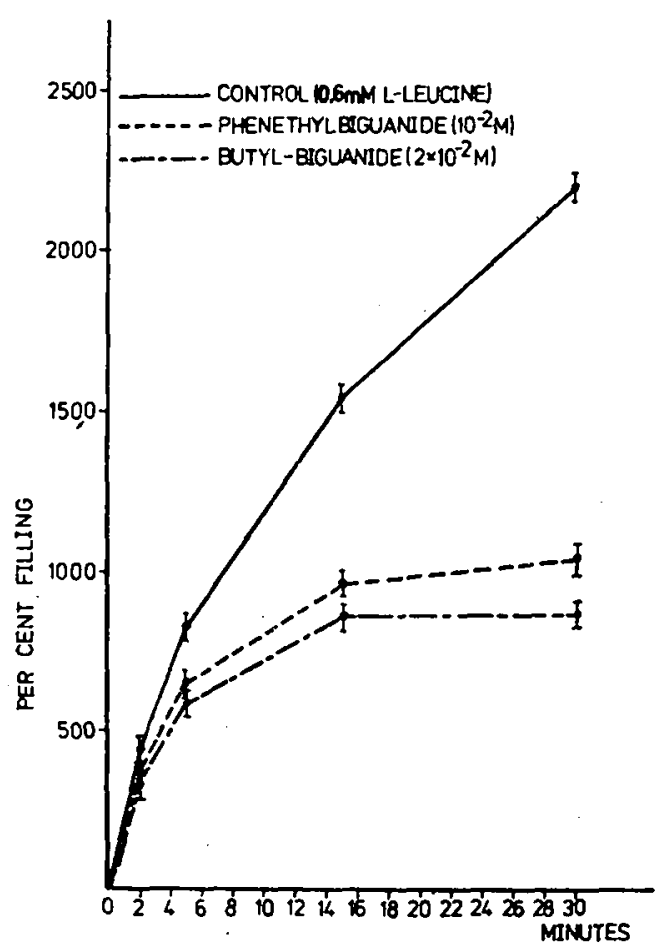

Fig. 6. Effect of phenethyl- and butylbiguanide an timedependent intestinal tissue accumulation of L-leucine. Substrate and inhibitor were added simultaneously. Incubation conditions are described in the method section. Results are means of 6 experiments and are expressed as means \pm SEM 
ides might, at least in the kidney, act through an inhibition of the second (ethacrynic acid-sensitive) sodium pump. As ATP-levels in the mucosal tissue have been found to be decreased after exposure of the intestine to biguanides [23], it seems, however, more likely that the inhibitory effect of biguanides on all energy-requiring transport processes in the intestine results from the known inhibitory effect of biguanides

Table 2. Effect of phenethylbiguanide on intestinal transport of low and high substrate concentrations of amino acids

\begin{tabular}{|c|c|c|c|c|c|}
\hline \multirow{2}{*}{ Substrate } & \multirow{2}{*}{$\begin{array}{l}\text { Substrate- } \\
\text { concentration }\end{array}$} & \multirow{2}{*}{$\begin{array}{l}\text { Phenethyl- } \\
\text { biguanide }\end{array}$} & \multicolumn{3}{|c|}{ Tissue-uptake } \\
\hline & & & $\begin{array}{l}\%- \\
\text { filling }\end{array}$ & & $\begin{array}{l}\% \%^{-} \\
\text {inhibition }\end{array}$ \\
\hline AIB & $\begin{array}{l}6 \times 10^{-5} \mathrm{M} \\
6 \times 10^{-5} \mathrm{M} \\
3 \times 10^{-2} \mathrm{M} \\
3 \times 10^{-2} \mathrm{M}\end{array}$ & $\begin{array}{l}\overline{10^{-2}} \mathrm{M} \\
\overline{10^{-2}} \mathrm{M}\end{array}$ & 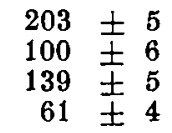 & $\begin{array}{l}(6) \\
(5) \\
(5) \\
(5)\end{array}$ & $\begin{array}{l}\overline{50.8^{8}} \\
\overline{58.1^{3}}\end{array}$ \\
\hline Glycine & $\begin{array}{l}6 \times 10^{-4} \mathrm{M} \\
6 \times 10^{-4} \mathrm{M} \\
3 \times 10^{-2} \mathrm{M} \\
3 \times 10^{-2} \mathrm{M}\end{array}$ & $\begin{array}{l}\overline{10^{-2}} \mathrm{M} \\
\overline{10^{-2}} \mathrm{M}\end{array}$ & $\begin{array}{l}399 \pm 18 \\
172 \pm 11 \\
207 \pm 9 \\
102 \pm 7\end{array}$ & $\begin{array}{l}(5) \\
(6) \\
(5) \\
(4)\end{array}$ & $\begin{array}{l}\overline{58.9^{\mathrm{a}}} \\
\overline{50.7^{\mathrm{a}}}\end{array}$ \\
\hline L-leucine & $\begin{array}{l}6 \times 10^{-4} \mathrm{M} \\
6 \times 10^{-4} \mathrm{M} \\
3 \times 10^{-2} \mathrm{M} \\
3 \times 10^{-2} \mathrm{M}\end{array}$ & $\begin{array}{l}10^{-2} \mathrm{M} \\
10^{-2} \mathrm{M}\end{array}$ & $\begin{aligned} 1712 & \pm 88 \\
303 & \pm 18 \\
101 & \pm 8 \\
54 & \pm 4\end{aligned}$ & $\begin{array}{l}(5) \\
(5) \\
(5) \\
(5)\end{array}$ & $\begin{array}{l}\overline{82.3^{\mathrm{a}}} \\
\overline{46.0^{\mathrm{a}}}\end{array}$ \\
\hline L-lysine & $\begin{array}{l}6 \times 10^{-4} \mathrm{M} \\
6 \times 10^{-4} \mathrm{M} \\
3 \times 10^{-2} \mathrm{M} \\
3 \times 10^{-2} \mathrm{M}\end{array}$ & $\begin{array}{l}\overline{10^{-2}} \mathrm{M} \\
\overline{10^{-2}} \mathrm{M}\end{array}$ & $\begin{array}{rr}449 & \pm 21 \\
124 & \pm 9 \\
100 & \pm 6 \\
54 & \pm 4\end{array}$ & $\begin{array}{l}(6) \\
(5) \\
(6) \\
(5)\end{array}$ & $\begin{array}{l}\overline{72.4^{8}} \\
\overline{45.0^{3}}\end{array}$ \\
\hline L-proline & $\begin{array}{l}3 \times 10^{-2} \mathrm{M} \\
3 \times 10^{-2} \mathrm{M}\end{array}$ & $\overline{10^{-2}} \mathrm{M}$ & $\begin{array}{r}128.8 \pm 6 \\
60.8 \pm 5\end{array}$ & $\begin{array}{l}(5) \\
(4)\end{array}$ & $\overline{52.8^{\mathrm{a}}}$ \\
\hline L-methionine & $\begin{array}{l}3 \times 10^{-2} \mathrm{M} \\
3 \times 10^{-2} \mathrm{M}\end{array}$ & $\overline{10^{-2}} \mathrm{M}$ & $\begin{array}{l}59.6 \pm 3 \\
32.4 \pm 4\end{array}$ & $\begin{array}{l}(4) \\
(4)\end{array}$ & $\overline{45.7^{3}}$ \\
\hline Myo-inositol & $\begin{array}{l}6 \times 10^{-5} \mathrm{M} \\
6 \times 10^{-5} \mathrm{M}\end{array}$ & $\overline{10^{-2}} \mathrm{M}$ & $\begin{array}{r}185 \pm 8 \\
91 \pm 5\end{array}$ & $\begin{array}{l}(7) \\
(8)\end{array}$ & $\overline{50.8^{\mathrm{a}}}$ \\
\hline
\end{tabular}

Segments of everted hamster small intestine were incubated for 45 min under the conditions indicated in the table in Krebs-Henseleit phosphate buffer under pure oxygen. Results are means \pm SEM.

${ }^{a} p<0.005$ comparing controls with phenethylbiguanide-incubated tissue. Number of experiments $(n)$ given in brackets. AIB $=\alpha$-amino-isobutyric acid.

Table 3. Effect of 2.4-dinitrophenol, ouabain and high concentrations of butylbiguanide on uptake of ${ }^{14} \mathrm{C}$. butylbiguanide $\left(10^{-5} M\right)$ by intestinal tissue

\begin{tabular}{lll}
\hline Conditions & $\begin{array}{l}\text { Incu- } \\
\text { bation } \\
\text { time } \\
\text { (min) }\end{array}$ & $\begin{array}{l}\text { Tissue uptake } \\
\text { (\%-filling) }\end{array}$ \\
& & \\
& 60 & $118 \pm 5$ \\
Control & 60 & $122 \pm 6 \mathrm{n} . \mathrm{s}$. \\
2.4-dinitrophenol $\left(5 \times 10^{-4} \mathrm{M}\right)$ & 60 & $90 \pm 5 \mathrm{p} 0.05$ \\
ouabain $\left(10^{-3} \mathrm{M}\right)$ & 60 & $122 \pm 6 \mathrm{n.s}$. \\
butylbiguanide $\left(10^{-2} \mathrm{M}\right)$ & 30 & $81 \pm 4$ \\
Control & 30 & $73 \pm 5 \mathrm{n} . \mathrm{s}$. \\
butylbiguanide $\left(10^{-4} \mathrm{M}\right)$ & 30 & $76 \pm 4 \mathrm{n} . \mathrm{s}$. \\
butylbiguanide $\left(10^{-3} \mathrm{M}\right)$ & 30 & $71 \pm 5 \mathrm{n} . \mathrm{s}$. \\
butylbignanide $\left(10^{-2} \mathrm{M}\right)$ & 30 & $76 \pm 4 \mathrm{n} . \mathrm{s}$. \\
phenethylbiguanide $\left(10^{-2} \mathrm{M}\right)$ & 30 \\
\hline
\end{tabular}

Segments of everted hamster small intestine were incubated for the time indicated in Krebs-Henseleit phos. phate buffer under the conditions indicated. Substrate was ${ }^{14} \mathrm{C}$-butylbiguanide in $10^{-5} \mathrm{M}$ cold carrier substance. Results are means \pm SEM.

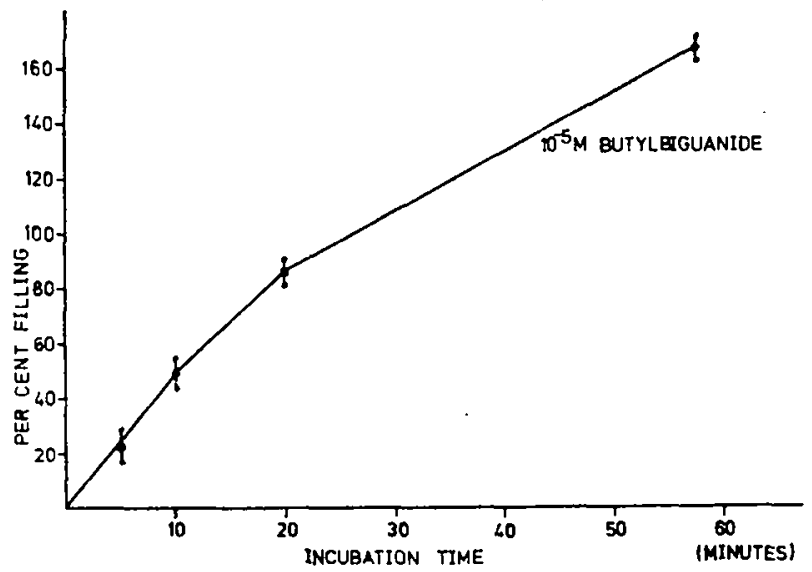

Fig. 7. Time-dependent intestinal tissue accumulation of 14C-n-butylbiguanide. Segments of everted hamster small intestine were incubated for time intervals as indicated in the graph with $10^{-6} \mathbf{M}$ butylbiguanidehydrochloride undier addition of ${ }^{14} \mathrm{C}$-butylbiguanide $(100000 \mathrm{dpm} / \mathrm{ml}$ incubation medium). Results of 6 experiments are given and expressed as means \pm SEM 
on mitochondrial respiration [16]. The slow onset of hexose [7] and amino acid transport inhibition in the intestine by biguanides and the more pronounced inhibitory effect after preincubation of the tissue with biguanides suggests that the drugs either act by an irreversible binding to the hexose or amino acid carrier sites or by entering the absorbing cells and acting from inside, possibly by competing with potassium for entry into the mitochondria and thus inhibiting mitochondrial respiration, as suggested by Davidoff [16]. Inhi. bition of respiration would then lead to a deprivation of energy required for translocation of actively transported solutes across the brush border membrane. The fact that biguanides did exert a stronger inhibitory effect on transport of amino acids from the cell interior than from the luminal side does not support an assumption of a $\mathrm{Na}^{+}$-substrate-carrier interaction. If biguanides act as competitive reversible inhibitors binding to the carrier-substrate recognition site, like the action of phlorizin on active glucose transport [1], it should have been possible to wash off the inhibitory effect of phenethylbiguanide, or higher substrate concentrations should have been able to overcome the inhibitory effect of biguanides exerted on low substrate concentrations. Rinsing of intestinal tissue which was loaded with biguanides did not abolish or diminish the inhibitory effect of biguanides on tissue uptake of L-methionine (Fig. 2).

Our data on the entry mechanism of biguanides into the mucosal epithelial cell suggests that uptake of butylbiguanide across the brush border membrane occurs through a diffusional mechanism with final distribution ratios achieving more than unity. Davidoff [16] reported that phenethylbiguanide achieved concentration gradients up to 100:1 in guinea pig heart mitochondria, but initial uptake rates of phenethylbiguanide into mitochondria did not give evidence for a saturating transport process using $10^{5}$-fold different concentrations of phenethylbiguanide [16]. Whether these concentration ratios are determined by transmembrane $\mathrm{pH}$-gradients or rather by transmembrane electrical potential differences cannot be decided. The inhibitory effect of ouabain on tissue uptake of butylbiguanide suggests that uptake of biguanides may be, at least in part, affected by the action of the sodium pump. Uptake of butylbiguanide was, how. ever, not energy-dependent.

Studies in humans using the segmental intestinal perfusion technique have shown an inhibition of glucose absorption after pretreatment of patients with therapeutic doses of biguanides [3,23]. The inhibitory effect of phenethylbiguanide in one study [3] was more than $50 \%$ and also showed an inhibition of water absorption from the intestine in humans. This means at least a delay of glucose absorption from the intestine will occur in paticnts treated with biguanides resulting in a decreased insulin response after an oral glucose load [19]. This effect may be even more potentiated after a meal than after intraduodenal application of the glucose load, for biguanides are known to inhibit gastric emptying $[11,22]$ in addition to their inhibitory effect on glucose absorption. Comparing the in vitro inhibitory effect of biguanides on active transport of hexoses [7] with the present data on the influence of biguanides on active transport of amino acids in vitro, it can be suggested that amino acid absorption may be in. hibited also in vivo after pretreatment with therapeutic doses of biguanides. As many amino acids are known to be strong stimulagtors of insulin secretion [18] a delay of intestinal amino acid absorption after pretreatment with biguanides may contribute to the lower insulin levels observed in patients on biguanide-treatment [2]. This assumption is supported by the observation of Czyzyk and coworkers [15]. They found decreased insulin and decreased $\alpha$-amino-nitrogen levels in the peripheral blood after an intraduodenal load of amino acids in patients pretreated with phenethylbiguanide. This effect might be explained by a delay of intestinal amino acid absorption after treatment with biguanides. As biguanides were shown to act as non-competitive inhibitors on amino acid uptake rates, affecting maximal transport capacity (Vmax) rather than $\mathrm{Km}$ of the transported solutes (Fig. 3), the inhibitory effect can be demonstrated at low and at high substrate concentrations (Table 2). Thus higher substrate concentrations cannot overcome the inhibitory effect exerted by biguanides.

The concentrations of biguanides used in our studies ranged from $5 \times 10^{-4} \mathrm{M}$ to $10^{-2} \mathrm{M}$. Such concentrations will never be achieved in the peripheral tissues after therapeutic doses of biguanides [12]. It is known, however, that the highest local concentrations of biguanides occur in the liver and the intestine [26]. An accumulation of the drug against a gradient can be shown in the small intestine in vitro (Fig. 7). As uptake of butylbiguanide did not show a saturation phenomenon, intracellular accumulations in the intestine may be even higher than the concentration of biguanides, in the intestinal lumen. If a $100 \mathrm{mg}$ tablet is diluted by $500 \mathrm{ml}$ of intestinal juice, the concentration of butylbiguanide in the lumen will be about $1 \mathrm{mM}$ and intracellular concentrations in the mucosa may be even higher. Thus after an oral therapeutic dose of biguanides concentrations will be achieved in the intestine which exerted, in our in vitro system, an inhibitory effect on amino acid transport.

From the results reported in the literature $[3,4,7$, $8,14,20,21,23,24]$ and the data presented in this paper it can be concluded that biguanides do inhibit several active, energy-requiring intestinal transport mechanisms, resulting in an inhibition or delay of intestinal nutrient absorption in vivo. If and how much this inhibitory effect participates in the blood glucose lowering effect of these oral antidiabetic drugs in diabetics can not yet be decided.

Acknowledgements. This work was suppcrted by $\Omega$ grant from the Dentsche Forschungsgomeinschaft (Ca 71/1). - We thank Miss A. Thinius and Miss H. Römbild 
for expert technical assistance. - Dr. R. Beckmann (Chemie Grünenthal, Stolberg/Rhld) kindly provided us with ${ }^{14} \mathrm{C}$-butylbiguanide.

\section{References}

1. Alvarado, F., Crane, R.K.: Phlorizin as a competitive inhibitor of the active transport of sugars by hamster small intestine in vitro. Biochim. biophys. Acta 56, 170 (1962).

2. Appels, A., Kattermann, R., Proschok, H., Hubrich, K., Frerichs, H., Söling, H.D., Creutzfeldt, W.: Untersuchungen über die Wirkung von Diät, Tolbutamid und Buformin sowie deren Kombination auf Körpergewicht und verschiedone Stoffwechselgrößon bei Diabotikern. I. Körpergewicht, Kohlenhydratstoffwechsel und immunologisch reagierendes Insulin. Diabetologia 4, 210-220 (1968).

3. Arvanitakis, C., Lorenzson, V., Olson, W.: Fffect of phenformin on glucose and water absorption in man. Gastroenterology 62, 837 (1972).

4. Biro, L., Bányász, T., Kovacs, M.B., Bajor, M.: Die Wirkung des Phenäthylbiguanids auf die Glucoseresorption. Klin. Wschr. 39, 760-762 (1961).

5. Caspary, W.F., Stevonson, N.R., Crane, R.K.: Evidence for an intermodiate step in carrier-mediated sugar translocation across the brush border membrane of hamster small intestine. Biochim. biophys. Acta 193, $168-178(1969)$.

6. Caspary, W.F., Crane, R.K.: Active transport of Myo-Inositol and its relation to the sugar transport system in hamster small intestine. Biochim. biophys. Acta 203, 308-316 (1970).

7. Caspary, W.F., Croutzfeldt, W.: Analysis of the inhibitory effect of biguanides on glucose absorption: Inhibition of active sugar transport. Diabetologia 7, $379-385$ (1971).

8. Caspary, W.F., Creutzfeldt, W.: Hommung des intestinalen Transportes von Aminosäuren und Calcium durch blutzuckersenkende Biguanide. Verh. dtsch. Ges. inn. Med. 77, 164-197 (1971).

9. Caspary, W.F., Crane, R.K.: Inclusion of L-glucose within the specificity limits of the active sugar trans. port system of hamster small intestine. Biochim. biophys. Acta 163, 395-400 (1969).

10. Crane, R.K., Mandelstam, P.: The active transport of sugars by various preparations of hamster intestine. Biochim. biophys. Acta 45, 460-476 (1960).

11. Creutzfeldt, W., Söling, H.D., Moench, A., Rauh, E., Bol, M.: Die Wirkung von $N_{1}$, n-Butylbiguanid (W 37) und $N_{1}, \beta$-Phenäthylbiguanid ( $W$ 32) auf den Alloxanund Phlorrhizin-Diabetes und die intestinale Glukoseabsorption von Ratten. Naunyn-Schmiedebergs Archiv: vide Arch. exp. Path. Pharmakol. 244, 31-47 (1962).

12. Creutzfeldt, W., Willms, B., Caspary, W.F.: The mechanism of action of the blood glucose lowering biguanides. In: Reports on oral diabctes therapy especially with HB 419. VII Congress of the Inter- national Diabetes Federation, Buenos Aires, 23-28 Angust, 1970. Excerpta Medica p. 95-106. Amsterdam: Elscvier Publ. Co.

13. Curran, P.F., Schultz, S.G.: Coupled transport of sodium and organic solutes. Physiol. Rev. 50, 637$718(1970)$.

14. Czyzyk, A., Lawecki, J., Sadowski, J., Ponikowska, J./ Szczpanik, Z.: Effect of biguanides on intestinal absorption of glucose. Diabetes 17, 492- 502 (1968).

15. Czyzyk, A., Lawecki, J., Malczowski, B., Rogala, H.: Effect of biguanides on amino acid-induced insulin secretion. Diabotologia 6, 41 (1970) (abstract).

16. Davidoff, F.: Effects of guanidino derivatives on mitochondrial function. J. biol. Chem. 246, 4017-4027 (1971).

17. Dixon, M., Wobb, E.C.: Enzymes, p. 329, $2^{\text {nd }}$ edition. New York: Academic Press 1964.

18. Floyd, J.C., Fajans, S.S., Conn, J.W., Knopf, R.F., Rull, J.: Stimulation of insulin secretion by amino acids. J. clin. Invest. 45, 1487-1502 (1966).

19. Hollobaugh, S. L., Rao, B., Kruger, F.A. : Studies on the site and mechanism of action of phenformin. I. Evidence for a significent "non-peripheral" effects of phenformin on glucose metabolism in normal subjects. Diabetes 19, 45-49 (1970).

20. Kruger, F.A., Altschuld, R.A., Hollobaugh, S.L.: Studies on the site and mechanism of action of phenformin. II. Phenformin inhibition of glucose transport by rat intestine. Diabetes $19,50-52(1970)$.

21. Love, A.H.G.: The effect of biguanides on intestinal absorption. Diabetologia 5, 422 (1969).

22. Mehnert, H., Förster, H.: Untersuchungen über den Mechanismus der Magenentleerung bei Mensch und Ratte nach oraler Applikation verschiedener Zucker. Diabetologia 4, 26-33 (1968).

23. Riecken, E.O., Bloch, R., Menge, H., Schaarschmidt, W.D., Gottesbühren, H., Goebell, D.: Biochemische, morphologische, funktionelle und histochemische Untersuchungen zur Phenforminwirkung ouf die Dünndarmschleimhaut bei Ratte und Mensch. Verh. dtsch. Ges. inn. Med. 77, 532-533 (1971).

24. Robinson, J.W.L., Luisier, A.L.: Die Wirkung von n-Butyl-Biguanid auf den Dünndarm- und Nierentransport von Zuckern und Aminosäuren. NaunynSchmiedebergs Archiv: vide Arch. exp. Path. Pharmakol. (in press).

25. Wiseman, G.: Absorption of amino acids. In : Handbook of physiology, Section 6, Vol. 3, Alimentary Canal, p. 1277-1307. Editor C.F. Code. Washington, D. C.: American Physiol. Society 1968.

26. Yoh, Y.J.: Distribution of n-butylbiguanide' ${ }^{1} \mathrm{C}$ hydrochloride in mouse tissues. Jap. J. Pharmacol. 17, $439-449$ (1967).

Dr. W.F. Caspary

Med. Universitätsklinik

D.3400 Göttingen

Humbold talleo 1

Federal Republic of Germany 